\title{
PROGRESS IN THE STUDY OF CLIMATIC EXTREMES IN NOR'THERN AND CENTRAL EUROPE
}

\author{
HEINO, R. ${ }^{1}$, BRÁZDIL, R. ${ }^{2}$, FØRLAND, E. ${ }^{3}$, TUOMENVIRTA, H. ${ }^{1}$, \\ ALEXANDERSSON, $\mathrm{H}^{4}{ }^{4}$, BENISTON, M. ${ }^{5}$, PFISTER, $\mathrm{C}^{6}{ }^{6}, \mathrm{REBETEZ}, \mathrm{M}^{7}$, \\ ROSENHAGEN, G. ${ }^{8}$, RÖSNER, $\mathrm{S}^{8}$, AND WIBIG, J. \\ 1 Finnish Meteorological Institute \\ P.O.Box 503, FIN-00101 Helsinki, Finland \\ 2 Masaryk University of Brno, Czech Republic \\ 3 Norwegian Meteorological Institute, Norway \\ 4 Swedish Meteorological and Hydrological Institute, Sweden \\ 5 University of Fribourg, Switzerland \\ 6 University of Bern, Switzerland \\ 7 Swiss Federal Institute for Forest, Snow and Landscape Research, Switzerland \\ 8 Deutscher Wetterdienst, Germany \\ 9 University of Lodz, Poland
}

\begin{abstract}
A study of the long-term changes of various climatic extremes was made jointly by a number of European countries. It was found that the changes in maximum and minimum temperatures follow, in broad terms, the corresponding well-documented mean temperature changes. Minimum temperatures, however, have increased slightly more than maximum temperatures, although both have increased. As a result, the study confirms that the diumal temperature range has mostly decreased during the present century in Northern and Central Europe. Frost has become less frequent. Two extreme-related precipitation characteristics, the annual maximum daily precipitation and the number of days with precipitation $\geq 10 \mathrm{~mm}$, show no major trends or changes in their interannual variability. An analysis of return periods indicated that in the Nordic countries there were high frequencies of 'extraordinary' 1-day rainfalls both in the 1930 s and since the $1980 \mathrm{~s}$. There have been no long-term changes in the number of high wind speeds in the German Bight. Occurrences of thunderstorms and hails show a decreasing tendency in the Czech Republic during the last 50 years. Finally, using proxy data sources, a 500-year temperature and precipitation event graph for the Swiss Mittelland is presented. It shows large interdecadal variations as well as the exceptionality of the latest decade 1986-1995.
\end{abstract}

\section{Introduction}

Climate fluctuations in Europe during the 20th century have been the topic of many investigations. There are well-documented long-term changes in the averages of climatic elements, such as a precipitation increase in north-western parts of Europe between the last two normal periods (Førland et al., 1996a), a springtime warming in Fennoscandia that started at the end of the last century (Tuomenvirta and Heino, 1996), and a warming of winters in Central Europe since the 1940s (e.g. Böhm, 1992). Some of the most comprehensive reviews 
dealing with climate variations over large areas of Europe are given by Brázdil and Koláŕ (1994), Heino (1994a), ECSN (1995) and Heikinheimo (1995).

In connection with the observed global warming, hypotheses about a possible increase in weather and climatic extremes have been formulated. However, as stated by Nicholls et al. (1996) 'overall, there is no evidence that extreme weather events, or climate variability, has increased, in a global sense, through the 20th century, although data and analyses are poor and not comprehensive. On regional scales there is clear evidence of changes in some extremes and climate variability indicators. Some of these changes have been toward greater variability, some have been toward lower variability'. Because the majority of available climatic change investigations has been oriented towards the average climate, we need more studies dealing with weather and climate extremes in different parts of the globe.

One of the basic objectives of the study in the area of climatic extremes is to analyse long time series of climatic elements by focusing on the tails of the frequency distributions. These often correspond to the events causing the greatest hazards to society and ecosystems, e.g. the greatest flood catastrophe of the 20th century in July 1997 in the Czech Republic, Poland and eastern Germany due to heavy precipitation. From this follows that the results of extreme-related studies have many practical applications. The probabilities of various extreme events and estimates of their return periods are of great value for the planning process of societies in order to avoid human or material losses. With good quality data, it is possible to study temporal variations of climatic extremes, and to improve the reliability of estimates related to the extremes.

Houghton et al. (1996) made some tentative assessments concerning future larger-scale extreme events based on climate modeling results. However, current climate models lack the accuracy at smaller scales and the integrations have not been long enough to permit analysis of local weather extremes. Also, feedbacks including the surface are important. For example, Beniston et al. (1995) found that as a result of the changes in seasonal mean values of temperature and precipitation between a $1 \times \mathrm{CO}_{2}$ and a $2 \times \mathrm{CO}_{2}$ simulation, there was decreased soil moisture content which was reflected in the statistical distribution of daily precipitation; July simulations for the $2 \mathrm{x} \mathrm{CO}_{2}$ indicated a sharp increase in the number of dry days with respect to current climate. These simulations made use of the Max-Planck-Institute ECHAM4 General Circulation Model (at T-106 resolution, i.e., $1.1 \times 1.1^{\circ}$ latitude/longitude resolution) and, nested within the GCM, the NCAR RegCM2 model at $20 \mathrm{~km}$ resolution.

It will be important to discover, whether the expected trends in the latest IPCC assessment (e.g. changes in the frequencies of extremely hot or cold days and an increase in precipitation amounts and intensity) can already be seen in the observational data records. Earlier studies have not provided many answers to these questions. Even small changes in the mean climate and its variability can 
be accompanied by relatively large changes in the frequency of extreme events. This has been seen both in theory (Katz and Brown, 1992) and in climate modelling (Kattenberg et al., 1996).

The topic of this paper is fluctuation and trend analyses for some characteristics of selected climatic and weather extremes. The time series of some selected stations from Northern (Finland, Norway, Sweden) and Central (Czech Republic, Germany, Poland, Switzerland) Europe are used for the investigations.

\section{Data and Homogeneity}

Climatic extremes can be defined as the occurrence of values of meteorological parameters, which lie above or below specific threshold values and occur with relatively low probability or which have significant impact on society or ecosystems. The corresponding threshold values can be determined more-or-less objectively by using a theoretical distribution of the given parameter (e.g. a normal distribution for maximum air temperatures, using values of the standard deviation) or subjectively, based on experience or knowledge of any interrelations (e.g. threshold values for the thermal stress of crops).

Traditionally, long-term climatic data sets in Europe have consisted mostly of monthly (mean) values. However, the work of the North Atlantic Climatological Dataset (NACD) and of the European Climate Support Network (ECSN) have produced new extensive European datasets which will support analyses of climatic extremes (e.g. Frich et al., 1996). Long-term records of climatic extreme elements for the Nordic countries are being compiled by the REWARD-project (Førland et al., 1998) and there are plans to compile a similar dataset for a larger area of Europe. In addition, vast climate extreme-related statistics are available for most European countries for the normal period 1961-1990.

We have compiled annual series of the following parameters (not all data were available for each of the seven investigated countries):

- mean daily maximum (Tmax) and minimum (Tmin) temperatures

- diurnal temperature range $(\mathrm{DTR}=\mathrm{Tmax}$ - Tmin $)$

- number of frost days $\left(\mathrm{Tmin}<0^{\circ} \mathrm{C}\right.$ )

- maximum 1-day ( $24 \mathrm{~h}$ ) precipitation

- number of days with precipitation greater than or equal to $10 \mathrm{~mm}$

- wind speed based on geostrophic wind

- number of occurrences of thunderstorms and hails.

The stations used in this study are shown in Figure 1. The study period has been 1901-1995, as far as possible. The data for this study were partly compiled from existing monthly series and partly from long-term daily climatic records in digital form. In future studies, the wider use of daily data would enable free 
selection of the length of events and of the limits of threshold values to be studied.

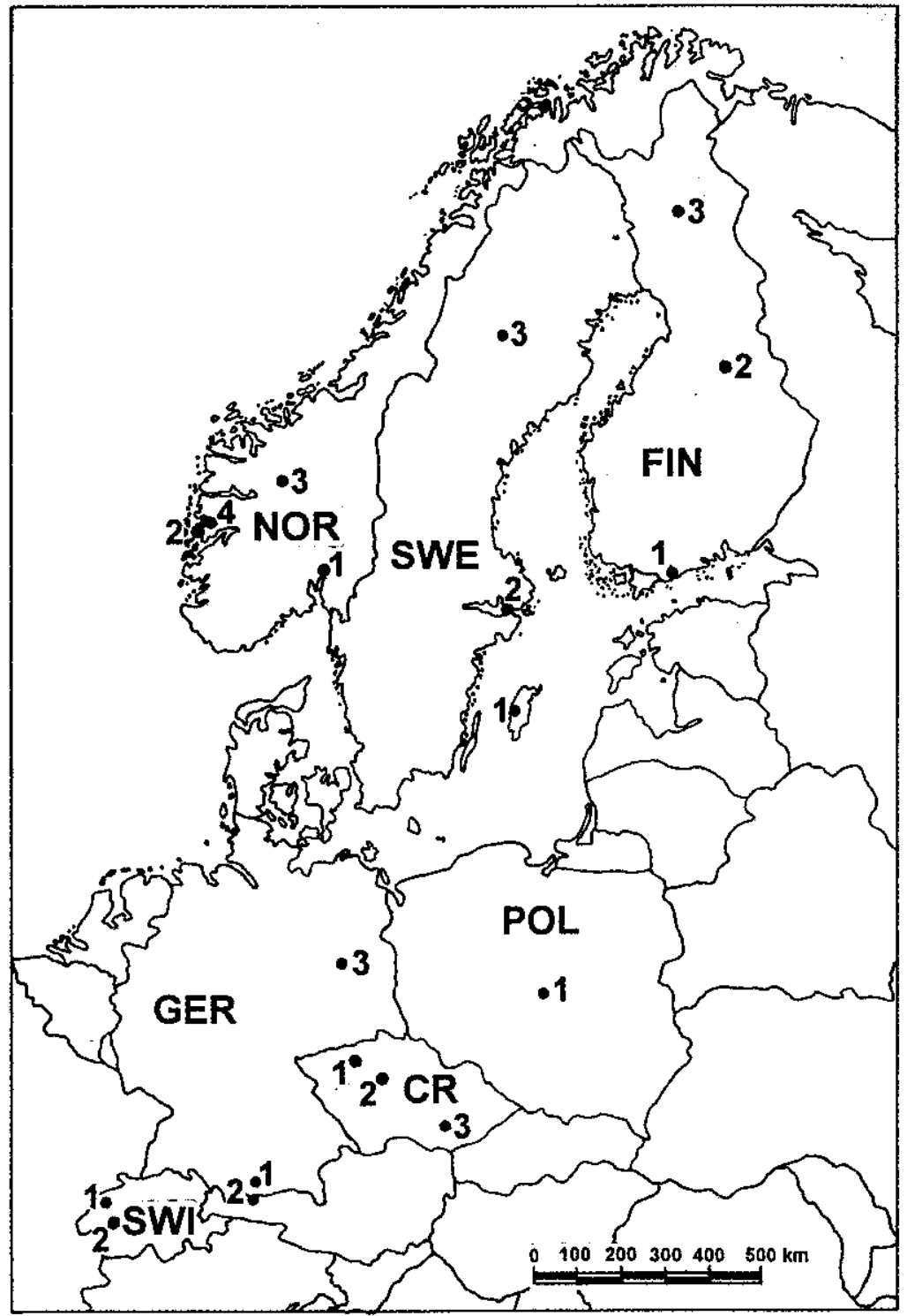

Figure 1. Geographical distribution of the stations used (cf. also Table I).

Czech Republic (CR): 1 Milešovka, 2 Prague-Klementinum, (Prague-Karlov, very close to PragueKlementinum), 3 Bmo-airport; Finland (FIN): 1 Helsinki, 2 Kajaani, 3 Sodankylä; Germany (GER): 1 Hohenpeissenberg, 2 Zugspitze, 3 Potsdam; Norway (NOR): 1 Oslo, 2 Bergen, 3 Skjaak, 4 Samnanger, 5 Tromsø; Poland (POL): 1 Lodz; Sweden (SWE): 1 Visby, 2 Stockholm, 3 Stensele; Switzerland (SWI): 1 Chateau-d'Oex, 2 Neuchatel. 
In climatology, the homogeneity of the data is important, especially in the study of climatic changes. Long-term changes due to real causative factors have been (and probably will be) small and slow and are hidden under large interannual variability. Climatic records, at least those which are readily available, are normally mixtures of both apparent and real variations. It is obvious that the apparent variations should be eliminated in order to get meaningful research results.

In practice, it is difficult to obtain long homogeneous data records. Various factors, such as changes in instruments and their exposure, observers, observation times, averaging methods, observation sites and their environments introduce inhomogeneities into the data. Many of the inhomogeneities are steplike changes (e.g. Figure 2) and typically alter the average value only. Application of relative homogeneity tests (e.g. Alexandersson, 1986; Easterling and Peterson, 1995) helps to find statistically significant inhomogeneities and adjust corresponding time series. But in the case of climatic extremes, application of the tests mentioned can be problematic because of the great temporal and spatial variability of many extremes.

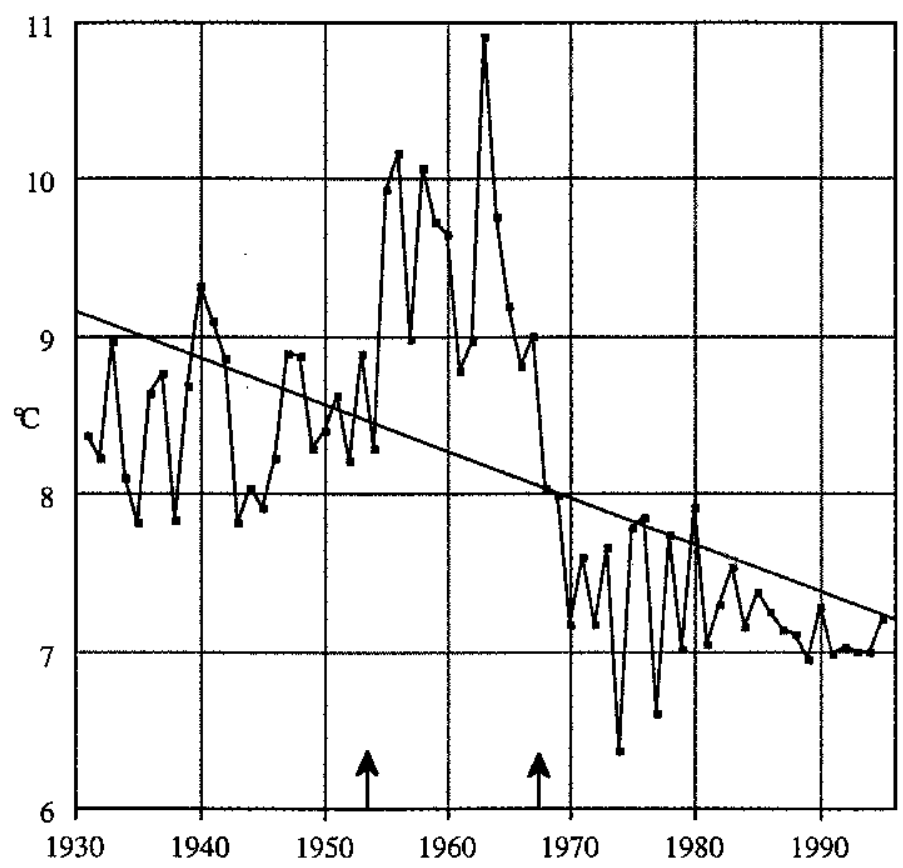

Figure 2. Difference between annual mean maximum and minimum temperatures $\left({ }^{\circ} \mathrm{C}\right)$ at Mikkeli, Finland $\left(61^{\circ} 44^{\circ} \mathrm{N}, 27^{\circ} 18 \mathrm{E}\right.$, altitude $\left.138 \mathrm{~m}\right)$ in $1931-1995$. This difference is strongly related to the station relocations indicated by the arrows. Any statistical analysis, like the linear trend line drawn, would give misleading results without the necessary adjustments, which can be done relatively easily with the help of the available metadata. 
An inhomogeneity may, moreover, also imply changes in variability or in other distribution parameters. In the automation of station networks, changes in maximum and minimum temperatures may become apparent, while the mean values may remain unchanged. In practice, the inhomogeneity of a secular time series is usually a combination of many factors. Information on the history of the measurements and the stations (metadata) is thus essential for a successful study of the data homogeneity and in making decisions about adjusting a series (cf. Heino, 1996). In this study the temperature data were in part adjusted for the most serious inhomogeneities; the other parameters were used as such, without any adjustments (cf. Table I).

Furthermore, several data series are from cities and may be progressively influenced by urban effects and their intensification. Upward temperature trends in urban stations are stronger than in the rural ones (cf. Heino, 1979, Brázdil, 1993, Brázdil et al., 1994). Because the increasing influence of the city has more or less gradual character and the estimation of its value is uncertain, it is problematic to remove it from temperature series.

Table I

Stations of this study with considerations of their homogeneity ( - no major homogeneity problems, + some inhomogeneities; further considerations on the data homogeneity are presented in connection with the analysis and results).

\begin{tabular}{|c|c|c|c|c|c|c|}
\hline \multirow[b]{2}{*}{ Milešovka (CR) } & \multicolumn{3}{|c|}{ Coordinates and altitude } & \multirow{2}{*}{$\begin{array}{l}\text { adjusted } \\
\text { records } \\
\text { no }\end{array}$} & \multirow{2}{*}{$\begin{array}{c}\begin{array}{c}\text { urban } \\
\text { environment }\end{array} \\
\text { no }\end{array}$} & \multirow{2}{*}{$\begin{array}{l}\text { homogeneity } \\
\text { estimation }\end{array}$} \\
\hline & $50^{\circ} 33^{\prime} \mathrm{N}$ & $13^{\circ} 56^{\prime} \mathrm{E}$ & $835 \mathrm{~m}$ & & & \\
\hline Prague-Klementinum (CR) & 5005 & 1425 & 191 & no & yes & - \\
\hline Helsinki (Fin) & 6010 & 2457 & 4 & no & yes & + \\
\hline Kajaani (Fin) & 6417 & 2741 & 134 & yes & no & + \\
\hline Sodankylä (Fin) & 6722 & 2639 & 179 & yes & no & - \\
\hline Hohenpeissenberg (Ger) & 4725 & 1101 & 977 & yes & no & - \\
\hline Zugspitze (Ger) & 4725 & 1959 & 2960 & yes & no & - \\
\hline Potsdam (Ger) & 5223 & 1304 & 81 & yes & yes & - \\
\hline Oslo (Nor) & 5957 & 1043 & 94 & no & yes & + \\
\hline Bergen (Nor) & 6025 & 0520 & 41 & no & yes & + \\
\hline Skjaak (Nor) & 6154 & 0810 & 432 & no & no & - \\
\hline Samnanger (Nor) & 6028 & 0554 & 370 & no & no & - \\
\hline Troms $\emptyset$ (Nor) & 6939 & 1856 & 100 & no & no & + \\
\hline Lodz (Pol) & 5144 & 1924 & 184 & no & yes & + \\
\hline Visby (Swe) & 5740 & 1820 & 42 & no & no & + \\
\hline Stockholm (Swe) & 5920 & 1803 & 44 & no & yes & + \\
\hline Stensele (Swe) & 6504 & 1709 & 325 & no & no & - \\
\hline Chateau-d'Oex (Swi) & 4629 & 0708 & 980 & no & no & - \\
\hline Neuchatel (Swi) & 4700 & 0657 & 487 & no & no & - \\
\hline
\end{tabular}




\section{Selected Climatic Extremes in Northern and Central Europe during the 20th Century}

\subsection{AIR TEMPERATURE}

\subsubsection{Maximum and minimum daily temperatures}

Daily maximum and minimum temperatures (Tmax, Tmin) are basic climatic parameters, which have been observed since the beginning of the 20th century in most European countries. However, these long-term records have not yet been fully used.

The motivation for many recent European studies devoted to investigations of Tmax and Tmin (for a list of them see e.g. Brázdil et al., 1996) was the paper by Karl et al. (1993). They showed that the Tmin of $37 \%$ of the global land mass increased three times more quickly than the corresponding Tmax during the period $1951-1990\left(0.84^{\circ} \mathrm{C}\right.$ and $0.28^{\circ} \mathrm{C}$, respectively). For Central Europe $(0.7 \%$ of the global land mass) the corresponding values were $0.60^{\circ} \mathrm{C}$ for Tmin and $0.52^{\circ} \mathrm{C}$ for Tmax (Brázdil et al., 1996).

Beniston et al. (1994) have shown that mean annual minimum temperatures in Switzerland have undergone a strong increase during the 20th century (about $2^{\circ} \mathrm{C} / 100$ years) while the increase in mean annual maximum temperatures has been much smaller.

Heino (1994b) studied the changes of Tmax and Tmin in Finland since the 1950s. The features of both cold (the 1960s and 1980s) and warm (mid-1950s and recent years) episodes are well reflected in the results. In addition, minimum temperatures showed a greater increase than maximum temperatures on an annual basis.

Brázdil et al. (1996) made a wide study of ten selected countries and regions in Central and Southeast Europe during the period 1951-1990, and also some analysed secular series covering the 20 th century. They concluded that there had been an increase in both annual maximum and minimum temperatures, for some regions a statistically significant one; however, minimum temperatures had increased more.

Gerstengarbe and Werner (1993) made a study of extreme climate events at several European stations up to 1990 . The investigation into the frequency of cold/ hot summers showed that e.g. during the period 1901-1927 there had been more than normal cold summers, while in 1928-1953 more than normal hot summers had been experienced. For 1954-1980 the numbers of cold and hot summers were nearly the same. In addition, the 95th percentile of the daily maximum temperature showed no significant trend. 
There is, quite naturally, a substantial coupling between series of mean temperature and of mean maximum and mean minimum and also of absolute maximum and absolute minimum temperatures. To illustrate this Table II gives correlation coefficients on a monthly and an annual basis for one station in northern Sweden.

Table II

Correlation coefficients (in hundredths) between monthly mean temperatures and various other temperatures (left column) at Stensele (Swe), 1860-1996.

\begin{tabular}{llllll}
\hline & J F M A M J J A S N N D & Y \\
\cline { 2 - 4 } & & & & & \\
Mean max. & 989892889394939290969798 & 93 \\
Mean min. & 989898908384827786979898 & 95 \\
& & & & & \\
Abs max. & 586854606467576958594056 & 19 \\
Abs min. & 788079615145485735817684 & 70
\end{tabular}

The somewhat lower correlations in spring and summer between mean temperature and mean minimum could be explained by the fact that anticyclonic months with sunny and warm days and high mean temperatures often include periods with fairly low night temperatures. For the connections with the absolute highest and lowest temperature the most surprising figures occur for the year as a whole with a very modest value for the maximum but considerably higher one for the minimum. This can be explained by the fact that the winter months with their large year-to-year variations dominate the annual means, and it is of course also during the winter months that the absolute minima occur.

\subsubsection{Diurnal temperature range}

As a result of the trends in annual maximum and minimum temperatures Karl et al. (1993) detected a decreasing trend in diurnal temperature range (DTR) during 1951-1990 over a large area of the globe. No human-induced local effects could provide a satisfactory basis for the widespread decrease in the DTR, while among many possibly natural variables, changes in cloudiness gave the best explanation of the decline. Recently, Easterling et al. (1997) came to the same conclusions with a more complete data set.

Heino (1994b) also shows a slight decrease in the DTR in Finland by approximately $0.5^{\circ} \mathrm{C}$ since the $1950 \mathrm{~s}$. The corresponding seasonal changes were also studied. It appeared that the decrease in the annual DTR is mostly explained by decreases in spring and summer, while the DTR in winter has remained at about the same level despite large inter-decadal changes. Cloudiness data from 
the stations used in the DTR calculations were found to be strongly correlated (about -0.8 ) with DTR on a monthly and seasonal basis. Since cloudiness has experienced a recent increase and the duration of sunshine a corresponding decrease, this appears to be a reasonable explanation of the DTR changes in Finland as well.

Brázdil et al. (1996) similarly made a wide review of the annual and seasonal DTR for Central and South-Eastern Europe. However, no significant trends were found for the annual DTR in the period 1951-1990 in most of the analysed regions (Germany, Poland, Slovak Republic, Austria, Hungary, Slovenia, lowland-Croatia and Bulgaria) except for the Czech Republic and the Swiss Mittelland. The trends in the DTR can be explained by cloudiness, since the correlation coefficients of annual DTR and cloudiness showed significant values, fluctuating between -0.60 (Bulgaria) and -0.83 (Hungary).

The evolution of the DTR in Northern and Central Europe was studied here with data sets covering the whole century (Table III and Figure 3).

Table III

Trend of the diurnal temperature range $\left({ }^{\circ} \mathrm{C} / 10\right.$ years) at each station in 1910-1995 (Prague 19101992), together with the statistical significance. Left column is the linear trend tested with two-sided t-test. Right column is Sen's nonparametric estimate of slope (Gilbert, 1987) and the significance of the trend is evaluated with nonparametric Mann-Kendall test (Sneyers, 1990);

(*5\%,**1\%,***0.1\%).

\begin{tabular}{lcc}
\hline station & linear trend & Sen's estimate \\
\hline Sodankylä (Fin) & -0.001 & $-0.063^{*}$ \\
Stensele (Swe) & $-0.057^{*}$ & $-0.056^{*}$ \\
Kajaani (Fin) & $-0.062^{* *}$ & $-0.068^{* *}$ \\
Bergen (Nor) & -0.025 & -0.021 \\
Helsinki (Fin) & 0.001 & 0.007 \\
Stockholm (Swe) & -0.001 & 0.004 \\
Visby (Swe) & $0.048^{* *}$ & $0.044^{*}$ \\
Potsdam (Ger) & $-0.055^{* *}$ & $-0.059^{* *}$ \\
Milešovka (CR) & $-0.038^{*}$ & -0.039 \\
Prague-Klementinum (CR) & $0.042^{*}$ & $0.040^{*}$ \\
Hohenpeissenberg (Ger) & $0.095^{* *}$ & 0.024 \\
Zugspitze (Ger) & $0.052^{* * *}$ & $0.050^{* * *}$ \\
Neuchatel (Swi) & $-0.236^{* * *}$ & $-0.241^{* * *}$ \\
& & \\
\hline
\end{tabular}

In addition to the linear trend a more resistant trend calculation by Sen's method (median slope between all possible pairs of values) was used with significance estimation as in Gilbert (1987). Both methods, however, gave quite similar results. 


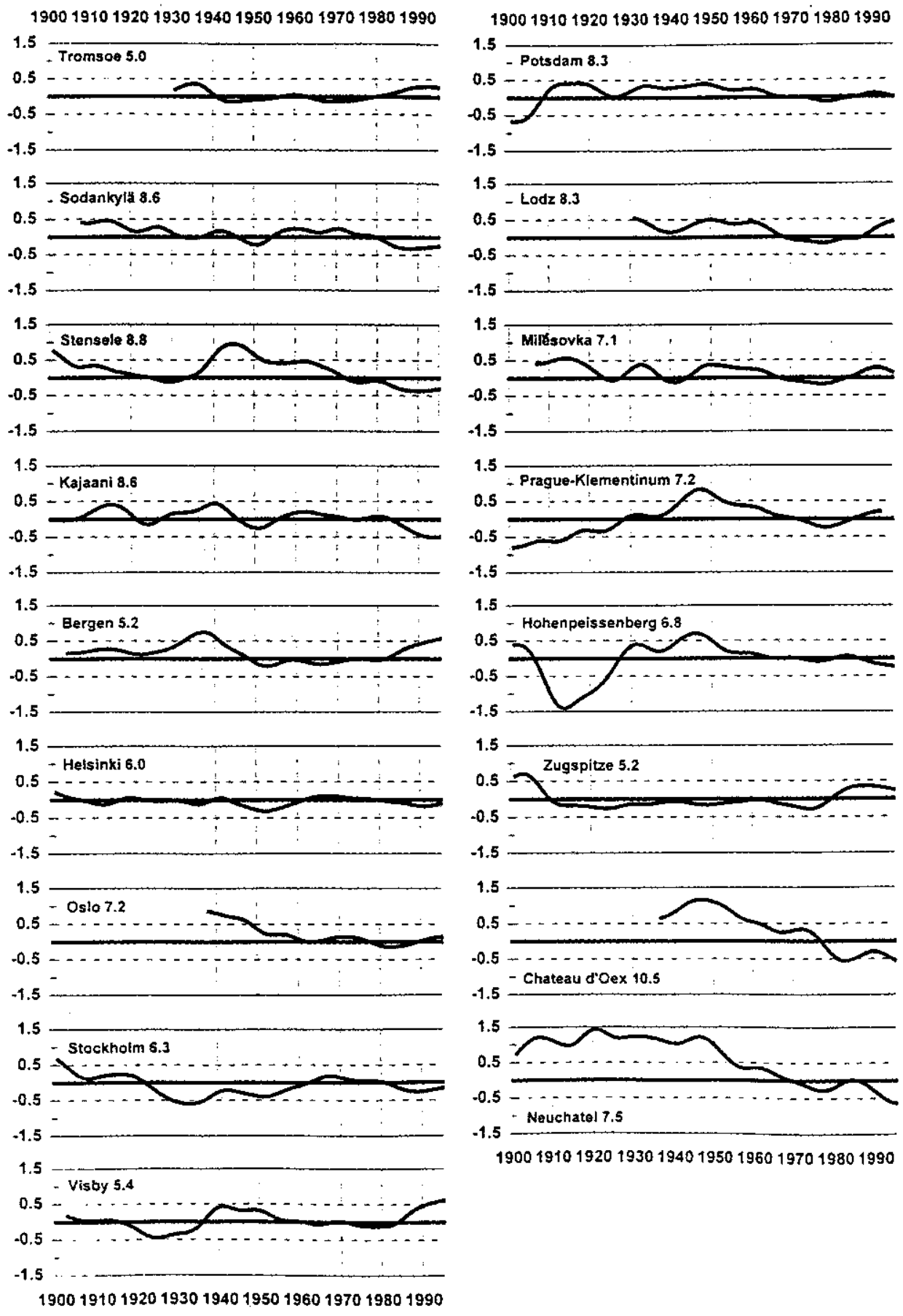

Figure 3. Annual anomalies of diurnal temperature range $\left(\mathrm{DTR},{ }^{\circ} \mathrm{C}\right)$; corresponding mean $\left({ }^{\circ} \mathrm{C}\right)$ after the station name. Curves are smoothed with a low-pass filter with Gaussian weighting coefficients equivalent to 10 year moving averages. Reference period: 1961-1990 
A decreasing trend since the 1940-50s is evident in most of the records, but at a few stations a recent increase is also seen. Before the 1940s there are more variable features (see also Brázdil et al., 1996).

In Hohenpeissenberg and Zugspitze the records are quite different from the others, but the increase of the DTR is statistically significant. In the Swiss data a general decreasing trend in the DTR, i.e. of approx. $2^{\circ} \mathrm{C}$ over the last 50 years, has been observed since about 1950 with a few higher values around 1990 at both sites. At Lodz there is also a recent statistically significant decreasing trend.

It should be emphasised that the DTR is more sensitive to non-homogeneities than is the mean temperature. For example, a relocation in a coastal area can give higher (inland relocation) or lower (relocation towards the coast) DTR-values, while the mean temperature would be less affected. In fact, this kind of relocation could explain the recent upward trend of the DTR-trends at Bergen and Visby, where the stations were moved inland in 1984 and 1986.

In addition, there has been a very strong trend towards a less open landscape that easily can give rise to false DTR-decreases for a number of stations. This tendency has many reasons (e.g. access to other fuels than wood, more buildings today around the houses than earlier, more fruit-trees, bushes etc. in gardens nowadays).

\subsubsection{Number of frost days}

The occurrence of frost has a considerable impact on many human activities, including the agricultural and construction industries. Since meteorological yearbooks contain standard monthly statistics on the number of days of maximum and minimum temperatures above/below certain limits, monthly counts of e.g. Tmin $<0^{\circ} \mathrm{C}$ are easily available. The year-to-year changes of some of these counts were also collected in this study.

For the detection of changes of climatic extremes, however, these indices are problematic as the counts depend on the local climate as well as threshold temperature chosen. Thus, while changes in mean temperatures were well reflected in the number of frost days (e.g. the warm 1930s and cold 1940s), in cold regions the counts reflected the changes in mean autumn and spring temperatures while in warm regions they reflected the change in winter temperatures, or even hardly appeared at all. For this reason the year-to-year variability is also smaller in the north than in the south.

However, it is very evident that some decrease of frost days has taken place since the 1930s (Table IV). For example, at both Swiss sites there are nowadays nearly 50 frost days less than in the early part of the record. This is linked to the very strong increase in winter minimum temperatures. The Finnish and Czech series also show decreasing tendencies. 


\section{Table IV}

Average of the annual number of frost days $\left(\mathrm{Tmin}<0^{\circ} \mathrm{C}\right)$ and linear trends in days $/ 10$ years, at some stations in 1931-1995, together with the statistical significance. Left column is the linear trend tested with two-sided t-test. Right column is Sen's nonparametric estimate of slope (Gilbert, 1987) and the significance of the trend is evaluated with nonparametric Mann-Kendall test (Sneyers, 1990); $(* 5 \%, * * 1 \%, * * * 0.1 \%)$.

\begin{tabular}{lccc}
\hline station & average & linear trend & Sen's estimate \\
\hline Sodankylä (Fin) & 225 & -0.79 & -0.87 \\
Kajaani (Fin) & 197 & 0.10 & 0.23 \\
Helsinki (Fin) & 136 & -1.45 & -1.17 \\
Milešovka (CR) & 146 & $-2.15^{*}$ & $-2.00^{*}$ \\
Prague-Karlov (CR) & 85 & $-3.11^{* *}$ & $-3.04^{* *}$ \\
Neuchatel (Swi) & 72 & $-7.46^{* * *}$ & $-7.40^{* * *}$ \\
Chateau d'Oex (Swi) & 154 & $-6.21^{* * *}$ & $-6.25^{* * *}$ \\
\hline
\end{tabular}

\subsubsection{Frequency distribution of extreme temperatures}

For the reasonable use of any time series it is essential to know the nature of the frequency distribution, but several statistical methods and models can be applied only if the time series considered is stationary, i.e. averages, variances and also higher moments do not vary with time. If the distribution of the climatic element in question is approximately normal (i.e. Gaussian), arithmetic means and standard deviations alone describe the distribution quite well. But Heino (1994b) has demonstrated that the skewness and kurtosis of frequency distributions are not fixed, but may vary considerably in the course of time.

An example of a change in the frequency distribution of temperature accompanying a shift in the mean is given in Figure 4. It illustrates the change in the probability density function of daily minimum temperatures between two distinct periods at Davos (eastern Alps, Switzerland). The period 1904-1910 corresponds to the coldest part of the century at this location, while 1988-1994 corresponds to the warmest part of the century. The shift of the entire distribution towards higher temperatures (and therefore lower frequencies of extreme low minimum daily temperatures) is quite obvious. Moreover, the skewness of the distribution shifts from approximately zero skewness (i.e., close to a Gaussian distribution) to negative skewness. This implies that there has been a gain in the upper range of the probability density function at the expense of the lower range of minimum temperatures. 


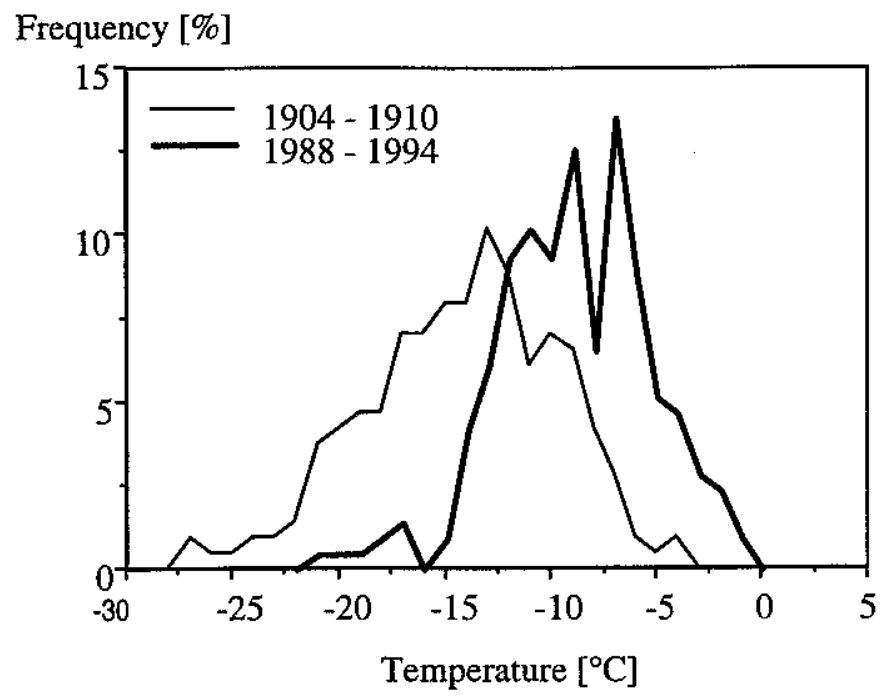

Figure 4. Frequency distribution of daily minimum temperatures $\left({ }^{\circ} \mathrm{C}\right)$ for two distinct periods at Davos, Switzerland $\left(46^{\circ} 50^{\prime} \mathrm{N}, 09^{\circ} 51^{\prime} \mathrm{E}\right.$, altitude $\left.1590 \mathrm{~m}\right)$.

\subsection{PRECIPITATION}

\subsubsection{Maximum daily precipitation}

3.2.1.1. Introduction. Every year flooding connected with heavy rainfall causes losses of human lives and enormous damage. Heavy 1-day rainfall plays a crucial role in the flooding in small watersheds and especially in urban areas. Monitoring maximum 1-day rainfall is therefore important both to deduce return period values and to detect any long-term trends in their occurrence. Longer-term totals of heavy precipitation are also needed, and for this kind of analysis, series of daily observations are also necessary.

The consequence of extreme high daily precipitation, mainly in the form of downpours or cloudbursts, can be flooding on a small scale. If heavy precipitation falls for several days, greater rivers and areas can be influenced by floods. This was the case for the catastrophic flood in July 1997 in Central Europe. It was the flood of the century in the Czech Republic and also affected the Oder river in Poland and eastern Germany.

The reason for the flooding was the heavy precipitation during 5-8 July 1997, when many stations in northern Moravia and Silesia recorded totals which were 2-3 times higher than the normal sum for the whole of July. On four occasions daily totals higher than $200 \mathrm{~mm}$ were reached in that area (e.g. on 6 July 1997 , Mt. Lysá hora at an altitude of $1324 \mathrm{~m}$ received $233.8 \mathrm{~mm}$ and Ostravice-Šance 
at an altitude of $445 \mathrm{~m} 230.2 \mathrm{~mm}$ ). In the Tatra Mountains high values were also recorded (e.g. $223 \mathrm{~mm}$ at Hala Gasiennicowa on 8 July).

The flood wave had not yet reached the lower course of the Oder river when, between July 18 and 21, heavy rain (over wide areas more than $100 \mathrm{~mm}$, at Mt. Praděd at an altitude of $1492 \mathrm{~m} 188 \mathrm{~mm}$, and at Mt. Lysá hora, $164 \mathrm{~mm}$ ) again poured down, seriously aggravating the situation at the already soaked dams.

3.2.1.2. Analysis. In the countries investigated the highest-ever 1-day precipitation amounts recorded during the 20th century are the following:

- Czech Repubilic: $240.2 \mathrm{~mm}$ at Nová Červená Voda (north Moravia) 9 July 1903

- Finland: $198.4 \mathrm{~mm}$ at Lahnus (close to Helsinki) 21 July 1944

- Germany: $260 \mathrm{~mm}$ at Zelthain (Saxony) 6 July 1906 and at Stein (Upper Bavaria) 8 July 1954

- Norway: $229.6 \mathrm{~mm}$ at Indre Matre (Western Norway) 26 November 1940

- Poland: $300 \mathrm{~mm}$ at Hala Gasiennicowa (Tatra Mountains) 30 June 1973

- Sweden: $237 \mathrm{~mm}$ at Karlaby (southern Sweden) 6 August 1960 (the next highest value, $198 \mathrm{~mm}$, was observed in Northern Sweden in July 1997).

Within the Nordic REWARD-project, a dataset of monthly values of maximum 1-day precipitation is being established. The dataset mainly covers the period 1890-1996, and contains more than 80 series from the Nordic countries. Preliminary analyses of these series indicate that there are large differences in the trend patterns even for neighbouring stations (Førland et al., 1998). For example, based on more than 150 series, it was possible to divide Norway into five regional groups with very similar trends in annual precipitation (HanssenBauer et al., 1997). But even within these well-defined regions, quite different trend patterns were found for annual maximum 1-day precipitation (Førland et al., 1998).

Just as in the temperature section, an example of the connection between mean values (monthly precipitation totals) and extremes (24-hour precipitation maximum) is given in Table V.

Table V

Correlation coefficients (in hundredths) between monthly precipitation totals and 24-hour maxima at Stensele (Swe), 1860-1996.

\author{
$\begin{array}{lllllllllllll}\text { J } & \text { F } & \text { M } & \text { A } & \text { M } & \text { J } & \text { J } & \text { A } & \text { S } & \text { O } & \text { N } & \text { D } & \text { Y }\end{array}$ \\ $\begin{array}{lllllllllllll}68 & 71 & 76 & 84 & 75 & 69 & 72 & 72 & 71 & 76 & 69 & 73 & 24\end{array}$
}


While there is a strong coupling on a monthly basis (the wettest day of the month contributes considerably to the total sum), the correlation is small $(0.24)$ on an annual basis. However, studies of other series indicate that 0.30 is a more typical value.

Examples of annual maximum 1-day precipitation from the analysed countries are shown in Figure 5 and Table VI. No major trends are seen and no changes in the year-to-year variability are found, either. Rising trends are evident at the German mountain stations, but only the trend at Zugspitze is statistically significant. At the Swiss and Finnish stations slight increasing trends are found, which are not, however, statistically significant.

Table VI

Linear trend of annual anomalies of 1-day maximum precipitation ( $\mathrm{mm} / 10$ years) at each station for 1910-1995, together with the statistical significance. Left column is the linear trend tested with twosided t-test. Right column is Sen's nonparametric estimate of slope (Gilbert, 1987) and the significance of the trend is evaluated with nonparametric Mann-Kendall test (Sneyers, 1990);

(*5\%,**1\%,***0.1\%).

\begin{tabular}{lcc}
\hline station & linear trend & Sen's estimate \\
\hline Sodankylä (Fin) & 0.08 & 0.00 \\
Tromsø (Nor) & -0.24 & -0.26 \\
Stensele (Swe) & -0.78 & -0.46 \\
Kajaani (Fin) & 0.52 & 0.59 \\
Skjaak (Nor) & -0.17 & -0.15 \\
Samnanger (Nor) & 0.13 & 0.00 \\
Helsinki (Fin) & 0.42 & 0.18 \\
Visby (Swe) & -0.26 & -0.09 \\
Potsdam (Ger) & 0.63 & 0.47 \\
Milešovka (CR) & -0.10 & 0.06 \\
Hohenpeissenberg (Ger) & 0.49 & 0.50 \\
Zugspitze (Ger) & $2.36^{* *}$ & $2.37^{* * *}$ \\
Neuchatel (Swi) & 0.37 & -0.05 \\
& & \\
\hline
\end{tabular}

There are several reasons for these diverging trend patterns for maximum 1-day precipitation:

- There are usually large local precipitation gradients in heavy rainfall events. Thus, even for long secular series, some stations may have experienced several 'accidental hits' of heavy rainfall, whereas neighbouring stations have no such 'hits' of precipitation at all. These local 'accidental hits' may be caused either by slow-moving frontal systems, by local quasi-stationary convective cells, or by local orographic rainfall enhancement. 


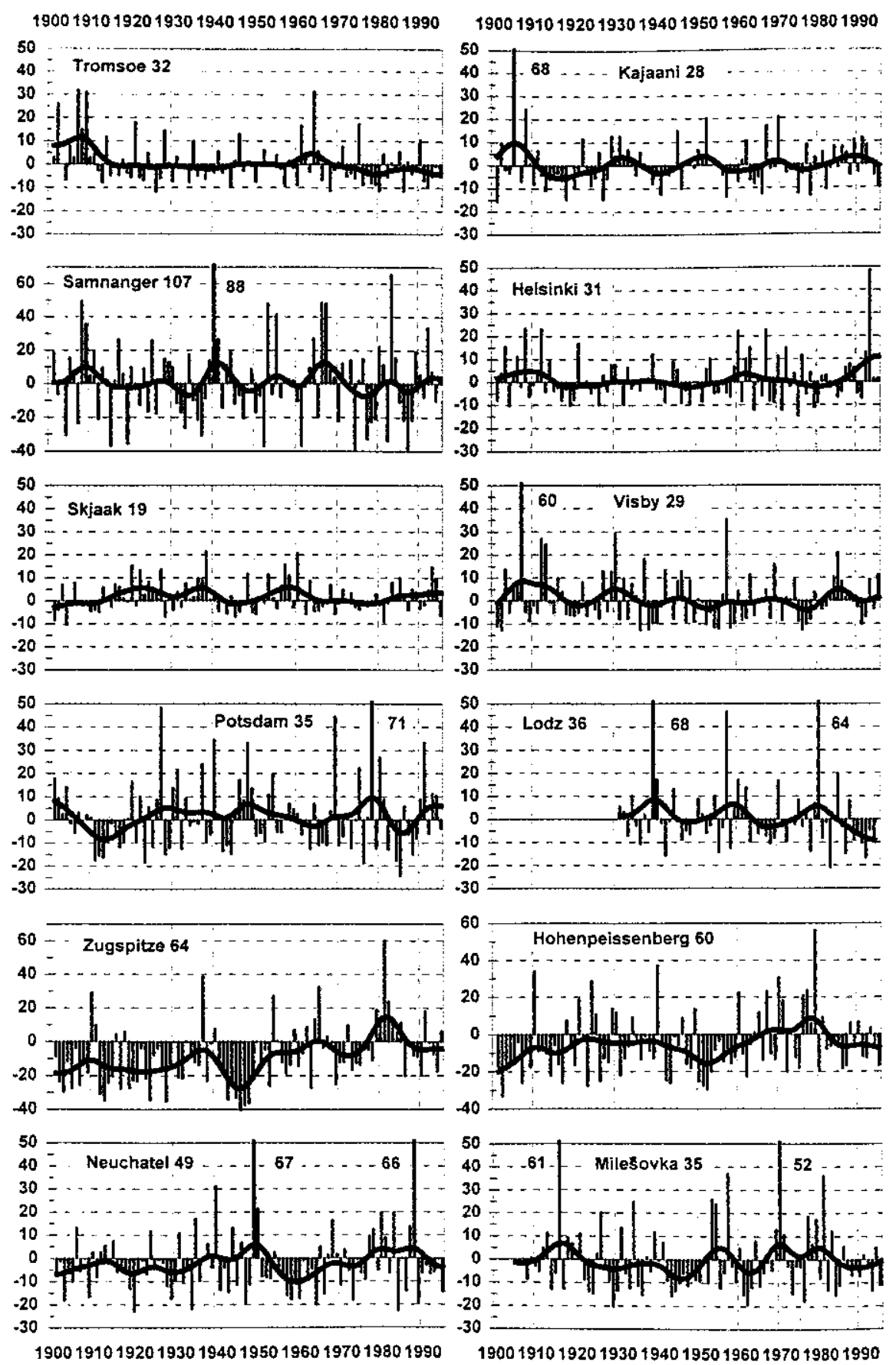

Figure 5. Annual anomalies of maximum 1-day precipitation ( $\mathrm{mm}$ ) for selected stations (corresponding mean after the station name), smoothed with a low pass filter with Gaussian weighting coefficients equivalent to 10 year moving averages. Reference period: 1961-1990. Data period 1901-1995 where possible. Single columns exceeding $50 \mathrm{~mm}$ are indicated by their values. 
- One local 'accidental' outlier may influence filtered trend curves for several years.

- 1-day precipitation values are very vulnerable to misreading and to erroneous sampling interval, e.g. the reading represents rainfall from a longer period than 24 hours. Most of these erroneous values are corrected by quality control systems, but in some cases it is difficult to judge whether an observation is true or false.

- An extreme 24-hour rainfall event may be split into two parts by the regular observing hours. Thus the trend in 1-day precipitation may be influenced by number of 'accidental hits' of extreme $24 \mathrm{~h}$ rainfall events being focused between 06-06 UTC.

- Inhomogeneities may seriously influence trends in series of annual precipitation (cf. Hanssen-Bauer and Førland, 1994; Heino, 1994b). However, for most of the causes of inhomogeneities (e.g. small relocations, installation of a wind shield, changes in instruments, changes in the environment), the adjustment factor will be smaller for heavy 1-day rainfall than for annual precipitation. This is because inhomogeneities mainly affect the measurement of snowfall and drizzle or small raindrops which are more influenced by airflow near the gauge.

Accordingly, a series of 1-day precipitation from a single station is not an ideal indicator for trend analyses in extreme rainfall. Conclusions concerning regional trends of maximum daily precipitation should be based on trend studies from a dense network of stations.

Rebetez et al. (1997) have shown for Switzerland that increases in extreme 3day precipitation in August and September are highly significant, implying that even if trends cannot be established in annual sums of precipitation (Beniston et al., 1994), they may be apparent in series for particular seasons or months.

For stations exposed to humid westerly winds in north-western Europe there is a coupling between precipitation totals and the North Atlantic Oscillation (NAO) index. Some of the monthly 1-day maxima also show a fairly strong connection with this large-scale index, as shown by data from the extremely wet Samnanger station in western Norway (Table VII).

Table VII

Correlation coefficients (in hundredths) between the NAO-index (monthly pressure difference between Ponta Delgada, Azores and Stykkisholmur, Iceland) and the monthly maximum 1-day precipitation at Samnanger (Nor), 1901-1996.

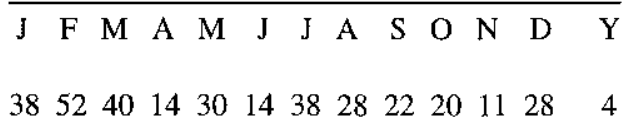


On the average there is a coupling on monthly basis. A vigorous Icelandic low (high value of the NAO-index) favours large daily precipitation maxima in western Norway. However, on an annual basis this connection is practically zero. Shorter interludes of strong cyclonic activity in the Iceland-Norway area can also give occasions of very large 1-day precipitation during a year having a low value on the NAO-index.

3.2.1.3. Applications. Precipitation amounts and intensity constitute important information for planning engineers. For example, in Germany, based on extreme event statistics maximum 15 min precipitation amounts with return periods of 1 year have been calculated for a certain location or area and have traditionally been used for the design of drainage systems. Today return periods of from 0.5 to 100 years for up to 18 duration times are used in the design of drainage systems. An increase in maximum daily precipitation may be a hint that the capacity of the drainage systems may be exceeded more often than expected. It is clear that upgrading a drainage system will be really costly.

In Germany extreme precipitation events have been investigated within the KOSTRA project. Data of 5 min precipitation amounts cover the period 19511980 (Bartels et al., 1997). In order to extract different return periods, Gumbel distributions (WMO, 1981) have been fitted to the data. The study shows that in general precipitation amounts increase from north-west to south-east. Looking e.g. at the $24 \mathrm{~h}$ precipitation amounts expected once a year, values vary from less than $35 \mathrm{~mm}$ in most parts of Germany to more than $80 \mathrm{~mm}$ in the Alps. A new project has just been set up to investigate the impact of climate change on hydrometeorology in Germany.

For the insurance industry in Norway, a precipitation event is characterised as 'extraordinary' if the return period is higher than 5-10 years, depending on the weather situation (frozen ground, combination with snow melt, preceding heavy precipitation, etc.).

For calculating return period values of 1-day precipitation, the Gumbel distribution is still that most commonly used (WMO, 1981). This distribution has also been used for analyses of maximum 1-day precipitation in the former Czechoslovakia (Šamaj et al., 1982) and for the Carpathian countries (Šamaj et al., 1985). By applying the Gumbel distribution to annual series, return period values for the series included in this study were calculated. For the Nordic countries, additional series from the REWARD-dataset were also used. Table VIII shows the frequencies of 1-day precipitation exceeding the 5-year return period value.

For the Nordic countries, Table VIII indicates higher frequencies of 'extraordinary' rainfalls in the 1930s and since the 1980s. Periods of high 1-day precipitation values seem to coincide well with hot summers. For the Central European series, the station density is too low to draw certain conclusions. 
Table VIII

Number of cases (per station and year) with maximum annual 1-day precipitation larger than the 5 year return period value in each decade.

\begin{tabular}{lccccccc}
\hline & FIN & SWE & NOR & GER & POL & CR & SWI \\
\hline No of stations & 10 & 20 & 24 & 3 & 1 & 2 & 2 \\
\hline $1900-09$ & 0.18 & 0.15 & 0.26 & 0.07 & - & - & - \\
$1910-19$ & 0.11 & 0.19 & 0.13 & 0.20 & - & - & - \\
$1920-29$ & 0.16 & 0.18 & 0.15 & 0.20 & - & 0.25 & - \\
$1930-39$ & 0.25 & 0.25 & 0.25 & 0.20 & 0.11 & 0.25 & 0.15 \\
$1940-49$ & 0.10 & 0.21 & 0.17 & 0.27 & 0.20 & 0.20 & 0.25 \\
$1950-59$ & 0.10 & 0.19 & 0.15 & 0.10 & 0.10 & 0.15 & 0.10 \\
$1960-69$ & 0.19 & 0.18 & 0.17 & 0.23 & 0.20 & 0.10 & 0.15 \\
$1970-79$ & 0.17 & 0.16 & 0.16 & 0.33 & 0.10 & 0.35 & 0.25 \\
$1980-89$ & 0.18 & 0.24 & 0.22 & 0.30 & 0.20 & 0.20 & 0.25 \\
$1990-96 *$ & 0.29 & 0.11 & 0.27 & 0.26 & 0.00 & 0.07 & 0.07 \\
*) 1990-94 for Germany and Poland & & & & & \\
\end{tabular}

\subsubsection{Precipitation days with totals $\geq 10 \mathrm{~mm}$}

Meteorological yearbooks have typically contained standard statistics on the number of days with precipitation exceeding specific amounts (e.g. 0.1, 1.0, 10.0 $\mathrm{mm}$ ). Series of their monthly values are therefore more easily available than complete series of daily precipitation.

The number of days with precipitation exceeding $10 \mathrm{~mm}$ (RD10) is one of the key elements for studying climatological extremes. However, it should be noted that RD10 is not a perfect indicator of extreme precipitation, either. At some stations daily precipitation of more than $10 \mathrm{~mm}$ occurs rather seldom, while it is no extreme at all at other stations, e.g. on the leeward side of the Norwegian mountains RD10 is less than 5 days/year at some stations, while in areas with orographically-enhanced precipitation in the western mountains it is more than 115 days/year (even every second day during the months September-December).

Examples of the variability and trends of RD10 are shown in Figure 6 and Table IX. Any long-term changes are difficult to see, except the increasing trends for the German mountain stations as well as that in Western Norway due to orography and circulation changes. 


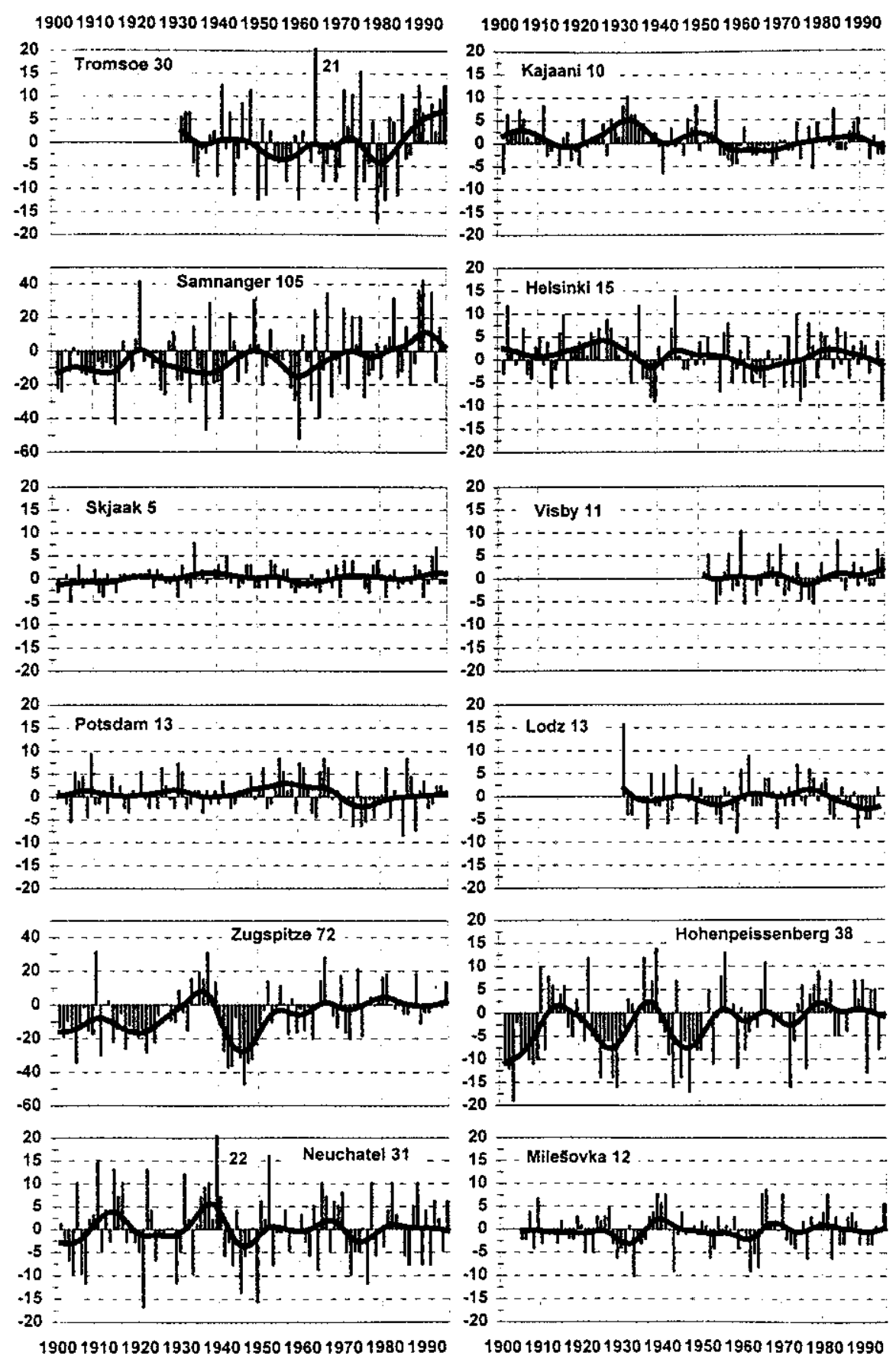

Figure 6. Annual anomalies of days with precipitation $\geq 10 \mathrm{~mm}$ for selected stations (corresponding mean in days after the station name), smoothed with a low-pass filter with Gaussian weighting coefficients equivalent to 10-year moving averages. Reference period: 1961-1990. Single columus exceeding $20 \mathrm{~mm}$ are indicated by their values. 
Table IX

Linear trends in the anomalies of the numbers of precipitation days per year $\geq 10 \mathrm{~mm}$ (days/10 years) at each station in 1910-1995, together with the statistical significance. Left column is the linear trend tested with two-sided t-test. Right column is Sen's nonparametric estimate of slope (Gilbert, $198 /$ ) and the significance of the trend is evaluated with nonparametric Mann-Kendall test (Sneyers, 1990): $(* 5 \%, * * 1 \%, * * * 0.1 \%)$.

\begin{tabular}{lcc}
\hline station & linear trend & Sen's estimate \\
\hline Sodankylä (Fin) & -0.07 & 0.00 \\
Kajaani (Fin) & -0.24 & -0.19 \\
Skjaak (Nor) & 0.05 & 0.00 \\
Samnanger (Nor) & $1.88^{*}$ & 1.56 \\
Helsinki (Fin) & -0.31 & -0.28 \\
Potsdam (Ger) & -0.06 & 0.00 \\
Milešovka (CR) & 0.19 & 0.16 \\
Hohenpeissenberg (Ger) & 0.21 & 0.27 \\
Zugspitze (Ger) & $1.59^{*}$ & $1.75^{*}$ \\
Neuchatel (Swi) & -0.22 & 0.00 \\
& & \\
\hline
\end{tabular}

The paper by Beniston et al. (1994) has shown that in Switzerland there is a strong interannual variability of precipitation, which does not allow any significant trend to be established; however, Rebetez (1995) has demonstrated that, particularly in summer, high monthly temperatures are correlated with low monthly precipitation. This is confirmed by modelling studies using highresolution Regional Climate Models centered over the Alpine region (Beniston et al., 1995; Marinucci et al., 1995; Rotach et al., 1997).

\subsection{OTHER SELECTED EXTREMES}

\subsubsection{Geostrophic wind in the German Bight}

In Central Europe, strong winds related to extratropical cyclones, causing widespread damage, have been observed in the 1990s (WMO, 1995). It was, therefore, necessary to study whether observations showed any long-term increase in strong winds.

Because observational records of wind speed and direction are highly biased due to changes in observational instruments and methods as well as the roughness of the environment, trends in extratropical storminess are best assessed by using indices based on sea-level pressure measurements or fields. Measurements of air pressure, even in the 19th century, can be assumed relatively homogeneous, given correct reduction to mean sea level, gravity and 
compensation for any change in observing hour. This is because the instrumentation has not changed much and air pressure is independent of surface characteristics. The geostrophic wind computed from the pressure readings of a few stations can thus be regarded as an estimate of the real wind. Any trend in the wind statistics will be reflected in the geostrophic wind statistics. By this method annual frequency distributions of daily wind can be obtained for long periods. However, small-scale and very short-term storms may not be detected by this method if daily, low-resolution (e.g. $150 \mathrm{~km}$ ) pressure gradients are used.

To ascertain whether storminess is really changing, a systematic examination of the geostrophic wind in the German Bight, in the south-eastern part of the North Sea, has been carried out (Schmidt and v. Storch, 1993).

The different data bases of pressure, thoroughly checked and evaluated, were as follows (Behrens and Schmidt, pers. comm):

- daily pressure data, one and three readings per day, for three stations around the German Bight for the period 1878 to 1992 ,

- all available pressure data for the region, taken from synoptic reports, usually 10 to 19 per day, analysed for time steps of three hours for the period 1949-1995. Pressure gradients and wind speeds estimated from the analysed maps may differ substantially from those estimated from the triangle of stations, because the maps can incorporate closed isobars and spatial changes of pressure gradient.

Figure 7 shows the annual percentage frequencies of geostrophic wind speed in the German Bight exceeding the stated threshold $(20 \mathrm{~m} / \mathrm{s})$, based on both the station-triangle and the mapped pressure fields.

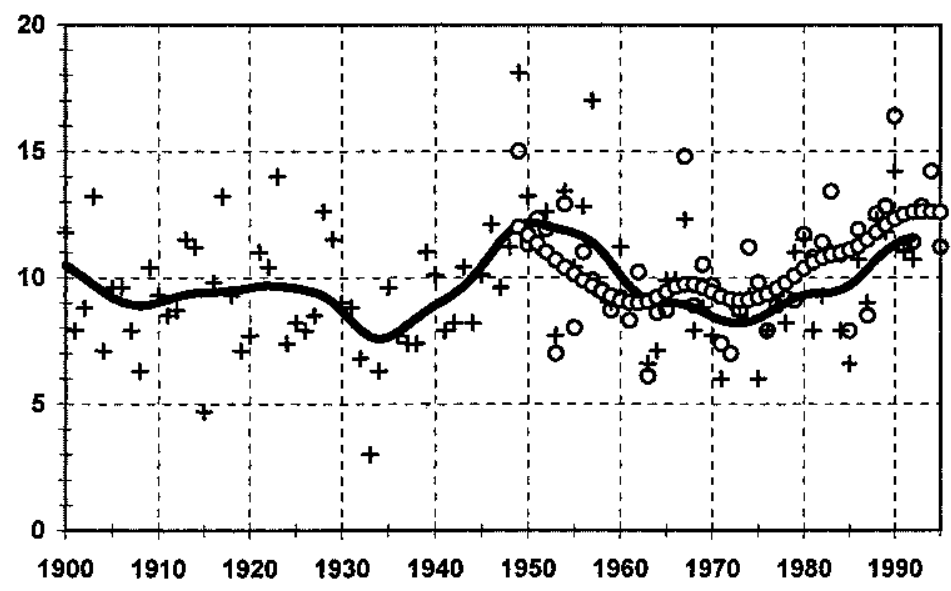

Figure 7. Annual percentage frequencies of geostrophic wind in excess of $20 \mathrm{~m} / \mathrm{s}$ in the German Bight, smoothed with a low-pass filter with Gaussian weighting coefficients equivalent to 10-year moving averages, period 1901-1992 with one observation per day (crosses/black line) and period 1949-1995 with 8 observations per day (circles/line of circles), cf. the text for further explanations. Reference period: 1961-1990 (Behrens and Schmidt, pers. comm.). 
The two methods give comparable results. Neither of the time series shows any indication of a long-term trend. Evaluations of the geostrophic wind for annual means or for higher wind speed thresholds also lead to the same conclusion.

The results presented here are in general agreement with analysis of the historical storm climate in north-western Europe (Alexandersson et al., 1998). The homogeneous storm indicators show no clear long-term trend, but a strong inter-decadal variability. The recent increase of storminess from around the 1960 s falls within the observed variability and the present level is comparable with that at the end of the 19th century.

\subsubsection{Thunderstorms}

Thunderstorms belong to a class of weather phenomena in which much damage occurs. This is due on the one hand to direct lightning strikes (deaths, fires), on the other hand to the accompanying phenomena of thunderstorms, such as hailstorms, downpours or cloud-bursts and strong wind gusts. For those characteristics which are not directly measured at the weather stations (e.g. other than the total precipitation, wind speed), their observation is affected by the capability of the observer. Since the possible homogenisation of series of local extreme weather phenomena is owing to the local nature of their occurrence, considerably limited, we are compelled to rely on the quality of the original observations. Although some papers investigating the fluctuation of thunderstorms and related weather extremes in the USA do exist (see e.g. Changnon, 1985; Changnon, 1997), on the European scale climatological analyses have a more or less traditional descriptive orientation.

Three professional weather stations in the Czech Republic were selected for analysis of the above phenomena during 1946-1995, namely the mountain observatory Milešovka (for more information see Stekl and Podzimek, 1993), the typical urban station Prague-Karlov and the more or less rural station Brnoairport (see Figure 1). The objective of the study was thunderstorms (at the station, i.e. within $3 \mathrm{~km}$ from the station - THUN), hailstorms (HAIL) and extreme precipitation represented by precipitation days with sum $\geq 20.0 \mathrm{~mm}$ (PREC). PREC includes not only heavy precipitation during downpours or cloud-bursts but also days with persistent frontal rainfall. During 1946-1995 there have been no changes in the methodology of observations. As an example, the series of annual frequencies of occurrence of THUN, HAIL and PREC obtained are presented in Figure 8 for Milešovka. The series are expressed as anomalies from the indicated 1961-1990 means.

For the THUN series the negative linear trends are statistically significant ( $5 \%$ level) for all three stations (Milešovka -1.45 cases/10 yrs, Prague-Karlov -1.39, Brno-airport -1.51), while for HAIL for Prague-Karlov (-0.39) and Brno 

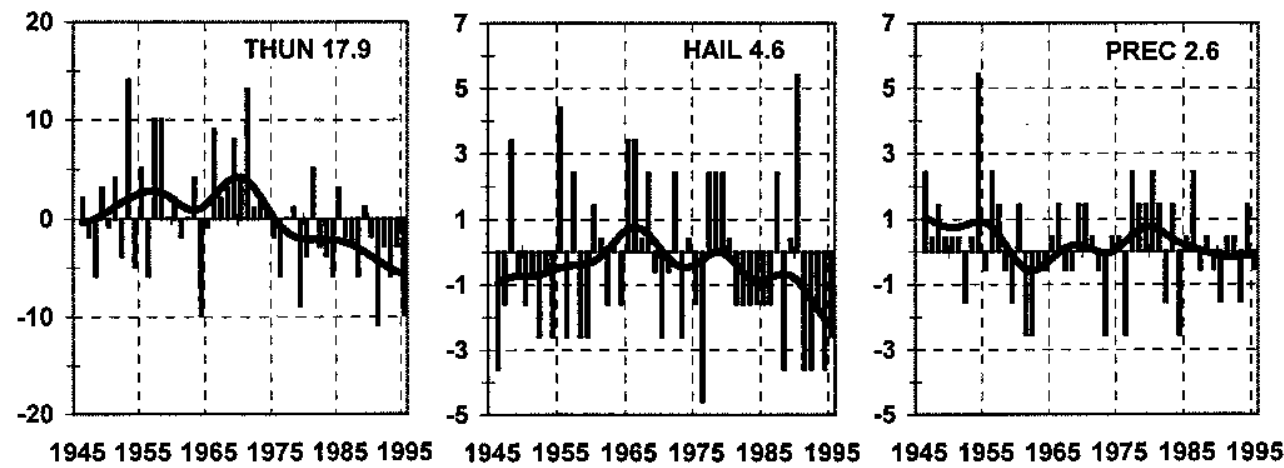

Figure 8. Annual deviations of frequencies of thunderstorms (THUN), hailstorms (HAIL) and heavy rainfall (PREC) at Milešovka (Czech Republic) in 1946-1995 (reference period 1961-1990, corresponding mean in days after the station name); smoothed with a low-pass filter with Gaussian weighting coefficients equivalent to 10 -year moving averages.

airport $(-0.17)$ and for PREC none of the negative trends is statistically significant. The decrease in annual frequencies of all three phenomena is related to the same tendency for the cyclonic weather types in which around $90 \%$ of these phenomena occur (Brázdil et al., 1998). Simultaneously during 1946-1995 a positive linear trend in annual air temperature in the area of the Czech Republic was observed $\left(0.15^{\circ} \mathrm{C} / 10 \mathrm{yrs}\right.$ - Brázdil and Macková, 1998).

From the practical point of view, the impacts of thunderstorms and related weather extremes are important. These were studied in the region of south Moravia in 1957-1995 (area around $9000 \mathrm{~km}^{2}$ ). As a source of information the regional newspaper Rovnost was used, in which reports about the damage, including picture documentation, appear. Out of the 135 records found, in $48.2 \%$ damage due to downpours and thunderstorms was reported, in $37.8 \%$ damage due to lightning, in $29.6 \%$ due to hail and in $14.1 \%$ due to gales. Cases with damage due to several factors overlap so the totals exceeds $100 \%$. In south Moravia the mean annual frequency of occurrence of an extreme phenomenon with damage was 3.5 for THUN (i.e. $6.3 \%$ of days with THUN), 1.0 for HAIL (i.e. $22.9 \%$ of days with HAIL) and 1.7 for PREC (i.e. $10.8 \%$ days with PREC) (Brázdil et al., 1998). This is consistent with Changnon (1997), who states that only 5 to $10 \%$ of all thunderstorms and 10 to $25 \%$ of all hailstorms produce damage. 


\subsection{CLIMATIC EXTREMES DERIVED FROM PROXY DATA}

Because instrumental records are relatively short, documentary evidence about weather and climate as well as other proxy data are used to construct long time series. Proxy data, however, must first be transformed to quantities equivalent to modern instrumental data, to allow correct interpretation of the concatenated series. An example is given from the Swiss Mittelland, the region between the Jura mountains and the Alps, where most of the population lives.

Preparation of these data involved two steps. In the first one the monthly temperature anomalies were defined. The data fall into an instrumental subperiod that begins with the temperature series of Basel in 1755 , and a preinstrumental sub-period preceding that year. Within the instrumental sub-period, anomalies are defined as departures from the 1901-1960 average of more than 180 per cent of the standard deviation. The anomalies of the pre-instrumental sub-period were estimated from documentary proxy data (observations of ice and snow features, phenological and biological observations), from tree-ring data and from descriptive data in historical documents. The values are expressed in terms of an index of seven discrete levels: $-3,-2,-1,0,+1,+2,+3$ (Pfister 1995; 1998).

In the second step the monthly anomalies were classified according to precipitation. For the instrumental sub-period (from 1864) the classification draws on an aggregate of four precipitation series from the main parts of the Mittelland and it is based on departures from the 1901-1960 average of this aggregate series. Months with a positive precipitation deviation of greater than 130 per cent of the standard deviation are designated 'wet', those with a negative precipitation deviation of more than 130 per cent of the standard deviation are designated 'dry'. Months within these thresholds are not designated. For the preinstrumental sub-period prior to 1864 the classification again draws on an index of seven discrete levels. This index is based on the number of rainy days from daily weather observations and information on severe floods. This combined temperature-precipitation classification thus yields six types of anomalies: Warm-wet, warm-dry, warm; cold-wet, cold-dry and cold (Figure 9). Anomalies in both periods include only index levels of -3 and +3 .

The following conclusions can be derived:

- The number of anomalies displays large fluctuations: In some decades (e.g. $1546 / 55,1656 / 65,1906 / 15$ ) anomalies hardly occurred at all, whereas in others (e.g. 1676-1685) they were abundant.

- Cold and dry anomalies are associated with persistent blocking anticyclones over the North Sea or Scandinavia (negative mode of the North Atlantic Oscillation) and advection of cold and dry continental air masses. Months of this type frequently occurred during the last two Little Ice Age events (late sixteenth 
to early seventeenth century) and 1810 to the late nineteenth century. They were rather rare between 1496 and 1565 and again from 1926 to 1995.

- The onset of the second Little Ice Age event stands out by virtue of a sudden 'cold' shift: Between 1556/65 and 1566/75 the number of cold anomalies increased sevenfold.

- The last decade from 1976/85 to $1986 / 1995$ stands out on account of a 'warm' shift in which the number of warm anomalies rose to its maximum over the last 500 years. In conjunction with worldwide evidence for rising temperatures and glacial retreat (Nicholls et al., 1996), this might be seen as an indication of global warming.

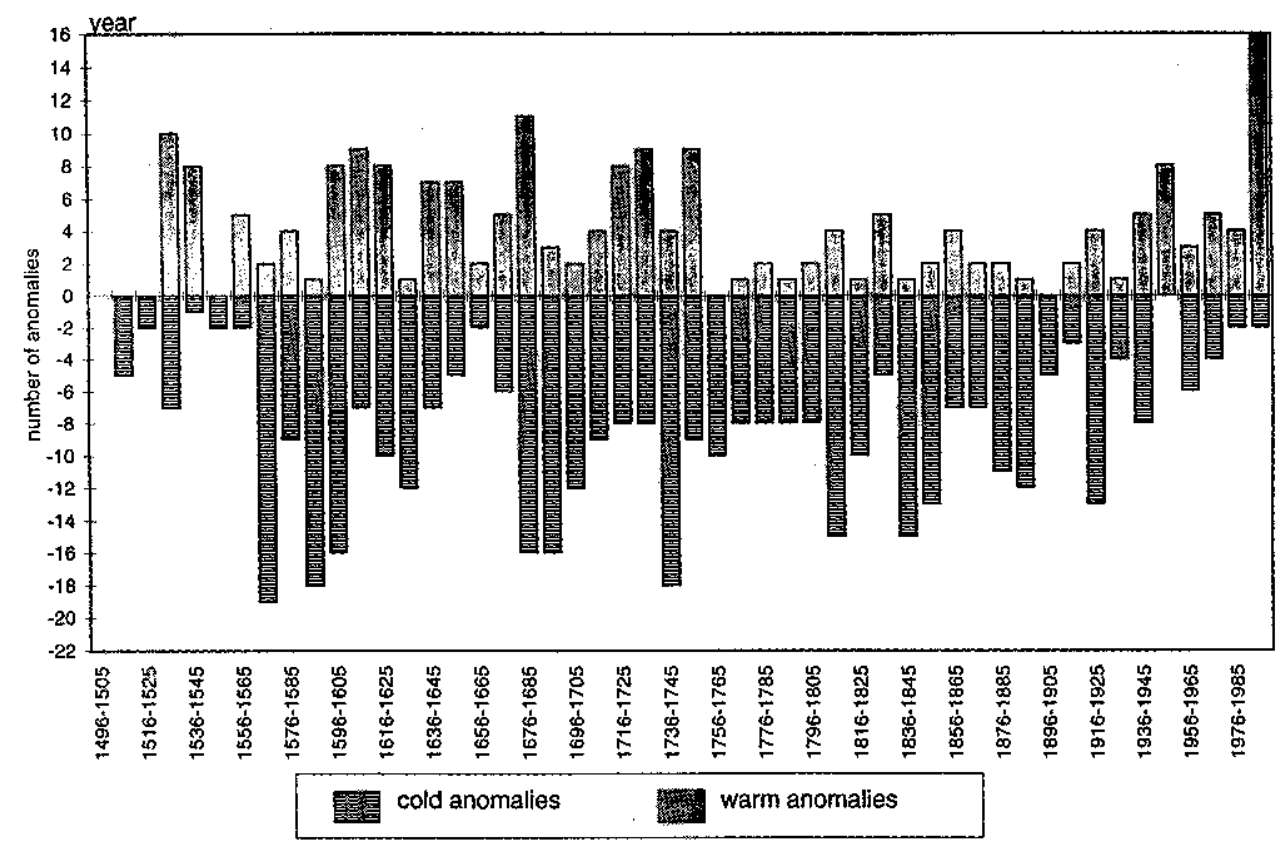

Figure 9 Number of monthly temperature and precipitation anomalies per decade in 1496-1995 in the Swiss Mittelland (cf. the text for further explanations).

\section{Concluding Remarks}

This paper has concentrated on some aspects of climatic extremes in Northern and Central Europe. Based on data for a few stations, results of the analysis of selected climatic elements were presented, mostly for the period 1901-1995. They include 
- a decrease in the diurnal temperature range (Figure 3, Table III)

- a decrease in the number of frost days (Table IV)

- no major change in daily precipitation extremes (Figure 5, Table VI)

- no major change in the number of precipitation days $\geq 10 \mathrm{~mm}$ (Figure 6)

- no long-term intensification of strong winds (Figure 7) and

- a decrease in occurrences of thunderstorms and hails (Figure 8).

Some of the extreme elements are very sensitive to various inhomogeneities in the data. However, the quality of the daily maximum and minimum temperatures can be improved using the same methods that are widely used for the homogenization of mean temperatures. Precipitation extremes are less sensitive to changes in station location or instrumentation, except at mountain stations. However, the normal quality checking procedures should be applied effectively. Homogenized air pressure data, on the other hand, provide a good possibility for analysis of wind speed extremes and other circulation parameters.

A new area in the study of climatic extremes is the use of proxy climatic data. Their calibration with long-term instrumental records provides the necessary ability to create extra long records for extreme studies also covering the preinstrumental period (Figure 9).

This study has revealed that extreme-related data sets are already partly ready or in preparation in many European countries. Regional action to collect the information on these data and subsequently, the data themselves, should be initiated in order to make the data available for global studies. Studies on climatic extremes in Europe and its regions need to extend beyond the traditional parameters of air temperature and precipitation. As discussed in this paper, the scope for weather and climate extremes to have impacts on nature and human society in densely populated Europe is very high. In this way Europe, with its dense network of stations and great potential of climatologists, can positively contribute to the third climate change assessment of the Intergovernmental Panel on Climate Change.

In addition to the purely observational-based studies on extremes, efforts need to be made, and are indeed currently taking place in a number of climate modelling centres, to investigate numerical model capabilities in simulating variability and extremes. Intuitively-reasonable variability can already be identified in high-resolution General Circulation Models. While models are still far from being accurate in terms of extremes, the prospects of using detailed Regional Climate Models to investigate extremes are improving. It should be stressed that extremes constitute the major stress factor on a number of environmental and associated socio-economic systems, and that if models are to be of use to the climate impacts community, they need to be capable of simulating current extreme event episodes, as well as the shifts in the extremes in relation to the changes in climate in the future. It is also in this sense that the 
joint efforts reflected in this paper will become increasingly important in the future, as a means of validating model simulations of extreme climatic events.

\section{Acknowledgements}

The authors would like to express their thanks as follows:

- H. Alexandersson, E. Førland, R. Heino and H. Tuomenvirta:

for financial support from the Nordic Council of Ministers to the REWARDproject (NMR-contract $\mathrm{FS} / \mathrm{HFj} / \mathrm{X}-93001$ )

- R. Brázdil:

for financial support from the Grant Agency of the Czech Republic (No. 205/95/0509 and 205/96/0527)

- C. Pfister:

for financial support from the Swiss National Science Foundation, Priority Programme Environment (No. 5001, 34888)

- M. Rebetez:

for the support of the Swiss Forest Investigation Programme

- G. Rosenhagen and S. Rösner:

for the contributions made by Jutta Herzog and Gerhard Müller-Westermeier.

In addition, all the authors express their thanks to the National Meteorological Services of their respective countries for providing the necessary data.

\section{References}

Alexandersson, H.: 1986, 'A homogeneity test applied to precipitation data', J. Climatol. 6, 661675.

Alexandersson, H., Schmith, T., Iden, K., and Tuomenvirta, H.: 1998, 'Long-term trend variations of the storm climate over NW Europe', Global Atmosphere-Ocean System (accepted).

Bartels, H., Malitz, G., Asmus, S., Albrecht, F.M., Dietzer, B., Günther, T., and Ertel, H.: 1997, 'Starkniederschlagshöhen für Deutschland, Deutscher Wetterdienst, Offenbach am Main.

Beniston, M., Rebetez, M., Giorgi, F., and Marinucci, M.R.: 1994, 'An analysis of regional climate change in Switzerland', Theor. Appl. Climatol. 49, 135 - 159.

Beniston, M., Ohmura, A., Rotach, M., Tschuck, P., Wild, M., and Marinucci, M.R.: 1995, 'Simulation of climate trends over the Alpine Region: Development of a physically-based modeling system for application to regional studies of current and future climate', Final Scientific Report Nr.4031 - 33250 to the Swiss National Science Foundation, Bern, Switzerland, $198 \mathrm{pp}$.

Brázdil, R.: 1993, 'The homogeneity of air temperature measurements Prague-Klementinum with respect to the intensification of the urban heat island', Zeszyty Naukowe Univ. Jagiell., Prace Geograficzne 95, 67-74. 
Brázdil, R., Machů, R. and Budíková, M.: 1994, 'Temporal and spatial changes in maxima and minima of air temperature in the Czech Republic in the period of 1951-1993', In: Brázdil, R. and Kolár̆, M. (Eds.), Contemporary Climatology, Brno, 93-102.

Brázdil, R. and Koláŕ, M. (Eds.): 1994, 'Contemporary Climatology', Proceedings of the Meeting of the Commission on Climatology of the International Geographical Union, Brno, $620 \mathrm{pp}$.

Brázdil, R., Budíkova, M., Auer, I., Böhm, R., Cegnar, T., Faško, P., Lapin, P., Gajic-Čapka, M., Zaninovic, K., Koleva, E., Niedzwiedz, T., Ustrnul, Z., Szalai, S., and Weber, R.O.: 1996, 'Trends of maximum and minimum daily temperatures in Central and Southeastern Europe', Int. J. Climatol. 16, 765-782.

Brázdil, R. and Macková, J.: 1998, 'Series of annual air temperatures for the Czech Republic in 1828-1995 (in Czech)', Meteorol. Zpr. 51, 17-21.

Brázdil, R., Štěpánek, P., and Vais, T.: 1998, 'Temporal and spatial analyses of thunderstorms, hailstorms and extreme precipitation in the south part of Moravia in 1946-1995 (in Czech)', Meteorol. Zpr. 51, 45-52.

Böhm, R.: 1992, 'Lufttemperaturschwankungen in Österreich seit 1775', Österr. Beitr. z. Met. u. Geophys. 5, 96 pp.

Changnon, D.: 1997, 'Damaging storms in the United States: selection of quality data and monitoring indices', In: Workshop on Indices and Indicators for Climate Extremes, NCDC, NOAA, Asheville, 3-6 June 1997, 24 pp.

Changnon, S.A.: 1985, 'Secular variations in thunder-day frequencies in the twentieth century', $J$. Geophys. Res. 90, 6181-6194.

Easterling, D.R. and Peterson, T.C.: 1995, 'A new method for detecting undocumented discontinuities in climatological time series', Int. J. Climatol. 15, 369-377.

Easterling, D., Horton, B., Jones, P., Peterson, T., Karl, T., Parker, D., Salinger, J., Razuvayev, V., Plummer, N., Jamason, P., and Folland, C.: 1997, 'Maximum and minimum temperature trends for the globe', Science 277, 364-366.

ECSN: 1995, 'Climate of Europe - Recent variation, present state and future prospects (First European Climate Assessment)', KNMI, De Bilt, 72 pp.

Førland, E.J., van Engelen, A., Ashcroft, J., Dahlström, B., Demaree, G., Frich, P., Hanssen-Bauer, I., Heino, R., Jonsson, T., Mietus, M., Müller-Westermeier, G., Pålsdottir, T., Tuomenvirta, H., and Vedin, H.: 1996a, 'Changes in 'normal' precipitation in the North Atlantic region (second edition)', DNMI Report 7/96 Klima, 27 pp.

Førland, E.J., Alexandersson, H., Frich, P., Hanssen-Bauer, I., Heino, R., Helminen, J., Jonsson, T., Nordli, P.Ø., Pålsdottir, T., Schmith, T., Tuomenvirta, H., and Tveito, O.E.: 1996b, 'REWARD, Progress report 01.01.1996 - 30.09.1996', DNMI-Report 30/96 KLIMA, 14 pp.

Førland, E. (coordinator), Alexandersson, H., Frich, P., Hanssen-Bauer, I., Heino, R., Helminen, J., Jonsson, T., Nordli, P.Ø., Pålsdottir, T., Schmith, T., Tuomenvirta, H., \& Tveito, O.E.: 1998, 'REWARD - Relating Extreme Weather to Atmospheric circulation using a Regionalized Dataset - Final Report' DNMI-Report 17/98 KLIMA, 23 pp.

Frich, P. (coordinator), Alexandersson, H., Ashcroft, J., Dahlström, B., Demaree, G.R., Drebs A., van Engelen, A., Førland, E.J., Hanssen-Bauer, I., Heino, R., Jonsson, T., Keegan, L., Nordli, P.Ø., Schmith, T., Stefffensen, P., Tuomenvirta, H., and Tveito, O.E.: 1996, 'North Atlantic Climatological Dataset (NACD Version 1) - Final report', European Commission (DG-XII), Environment Programme, Contract (EV5V CT93-0277), Danish Meteorological Institute, Scientific Report, 96-1, 47 pp.

Gerstengarbe, F.-W. and Werner, P.C.: 1993, 'Extreme klimatologische Ereignisse an der Station Potsdam und an ausgewählten Stationen Europas', Berichte des Deutschen Wetterdienstes $\mathrm{Nr}$. I86, Offenbach am Main. 
Gilbert, R.O.: 1987, 'Statistical methods for environmental pollution monitoring', Van Nostrand Reinhold Co., New York, 320 pp.

Hanssen-Bauer, I. and Førland, E.J.: 1994, 'Homogenizing long Norwegian precipitation series', $J$. Climate 7, 1001-1013.

Hanssen-Bauer, I., Førland, E.J., Tveito, O.E., and Nordli, P.Ø.: 1997, 'Estimating regional precipitation trends - comparisons of two methods', Nordic Hydrology 28, 21-36.

Heikinheimo, P. (Ed.): 1995, 'International Conference on Past, Present and Future Climate. Proceedings of the SILMU conference held in Helsinki, Finland 22-25 August 1995'. Publications of the Academy of Finland 6/95, Helsinki, 490 pp.

Heino, R.: 1979. 'Urban effect on climatic elements in Finland.' Geophysica 15, p. 171-188.

Heino, R. (Ed.): 1994a, 'Climate variations in Europe. Proceedings of the European Workshop held in Kirkkonummi (Majvik), Finland 15-18 May 1994', Publications of the Academy of Finland 3/94, Helsinki, 386 pp.

Heino, R.: 1994b, 'Climate in Finland during the period of meteorological observations', Finnish Meteorological Institute Contributions 12, $209 \mathrm{pp}$.

Heino, R.: 1996, 'Data homogeneity and metadata', In: Obrebska-Starkel, B. \& Niedzwiedz, T. (Eds.): Proceedings of the Intemational Conference on Climate Dynamics and the Global Change Perspective, Cracow, Poland, 17-20 October 1995, p. 13-21.

Houghton, J.T., Meira Filho, L.G., Callander, B.A., Harris, N., Kattenberg, A., and Maskell, K.: 1996, 'Climate Change 1995 - The Science of Climate Change', Intergovernmental Panel on Climate Change, Cambridge Univ. Press, 572 pp.

Karl, T.R., Jones, P.D., Knight, R.W., Kukla, G., Plummer, N., Razuvayev, V., Gallo, K.P., Lindseay, J., Charlson, R.J., and Peterson, T.C.: 1993, 'A new perspective on recent global warming: Asymmetric trends of daily maximum and minimum temperature', Bull. Amer. Meteor. Soc. 74, 1007-1023.

Kattenberg, A., Giorgi, F., Grassl, H., Meehl, G., Mitchell, J., Stouffer, R., Tokioka, T., Weaver, A. and Wigley, T.: 1996, 'Climate models - Projections of future climate', In: Houghton, J.T., Meira Filho, L.G., Callander, B.A., Harris, N., Kattenberg, A., and Maskell, K. (Eds.): 1996, Climate Change 1995 - The Science of Climate Change, Intergovernmental Panel on Climate Change, Cambridge Univ. Press, 285-357.

Katz, R.W. and Brown, B.G.: 1992, 'Extreme events in a changing climate: Variability is more important than averages', Climatic Change 21, 289-302.

Marinucci, M. R., Giorgi, F., Beniston, M., Wild, M., Tschuck, P., and Bernasconi, A.: 1995, 'High resolution simulations of January and July climate over the Western Alpine region with a nested regional modeling system', Theor. Appl. Climatol. 51, 119-138.

Nicholls, H., Gruza, G., Jouzel, J., Karl, T., Ogallo, L., and Parker, D.: 1996, 'Observed climate variability and climate', In: Houghton, J.T., Meira Filho, L.G., Callander, B.A., Harris, N., Kattenberg, A. and Maskell, K. (Eds.): Climate Change 1995 - The Science of Climate Change, Intergovernmental Panel on Climate Change, Cambridge Univ. Press, 133-192.

Pfister, C.: 1995, 'Monthly temperature and precipitation in central Europe from 1525-1979: quantifying documentary evidence on weather and its effects', In: Bradley, R. S. and Jones, P. D. (Eds.), Climate since A.D. 1500', Routledge, London, 118-142.

Pfister, C.: 1998, 'Wetternachhersage, 500 Jahre Klimavariationen und Naturkatastrophen 14961995', Bern (Haupt).

Rebetez, M.: 1995, 'Seasonal relationship between temperature, precipitation and snow cover in a mountainous region', Theor. Appl. Climatol. 54, 99-106.

Rebetez, M., Lugon, R., and Baeriswyl, P.-A.: 1997, 'Climatic change and debris flows in high mountain regions: the case study of the Ritigraben torrent (Swiss Alps)', Climatic Change 36, 371-389. 
Rotach, M. W., Marinucci, M. R., Wild, M., Tschuck, P., Ohmura, A., and Beniston, M.: 1997, 'Nested regional simulations of climate change over the Alps for the scenario of a doubled greenhouse forcing', Theor. Appl. Climatol. (in press).

Šamaj, F., Valovič, Š., Brázdil, R., and Gulčíková, V.: 1982, 'Maximum daily totals of atmospheric precipitation in the CSSR (in Czech)', Meteorol. Zpr. 35, 129-135.

Šamaj, F., Valovič, Š., and Brázdil, R.: 1985, 'Daily precipitation sums with extraordinary intensity in the CSSR in 1901-1980 (in Slovak)', Zbornik prác Slovenského hydrometeorologického ústavu 24, 9-112.

Schmidt, H. and v. Storch, H.: 1993, 'German Bight storms analysed', Nature 365, 791.

Sneyers, R.; 1990, 'On the statistical analysis of series of observations', Technical Note 143, WMO No. 415,192 pp.

Von Storch, H., Guddal, J., Iden, K.A., Johnson, T., Perlnitz, J., Reistad, M., Ronde, de, J., Schmidt, H., and Zorita, E.: 1993, 'Changing statistics of storms in the North Atlantic', MPI report, No. $116,19 \mathrm{pp}$.

Stekl, J. and Podzimek, J.: 1993, 'Old mountain meteorological station Milešovka (Donnersberg) in Central Europe', Bull. Amer. Meteorol. Soc. 74, 831-834.

Tuomenvirta, H. and Heino, R.: 1996, 'Climatic changes in Finland - recent findings', Geophysica 32, 61-75.

WMO: 1981, 'Selection of distribution types for extremes of precipitation', WMO-No. 560, Operational Hydrology Rep.15, World Meteorological Organization, Geneva, 64 pp.

WMO: 1995, 'The Global Climate System Review', WMO-No. 819, World Meteorological Organization, Geneva, $150 \mathrm{pp}$.

(Received 5 November 1997; in revised form 1 September 1998) 